\title{
A Note on an Alternative Approach to Affirmative Action
}

\section{Gering}

KPMG Management Consulting, Johannesburg

\begin{abstract}
Counting in the form of statistical data is almost always a good indicator of past and present discrimination; counting as an action plan in the form of a quota is usually not. This article examines the issue of affirmative action from the perspective of an analytical approach developed and published in the context of higher education between 1983 and 1986. It is shown how these ideas are being extended as a proactive tool in the context of changing management projects.
\end{abstract}

\section{INTRODUCTION}

Despite the fact that the majority of their work force is black, many South African companies have filled their top and middle management positions predominantly with white managers. The inequality has a historical cause and the political pressure to redress balance is mounting. This is compounded by the apartheid heritage in which talented black managers often lack the training and experience of equivalent managers in other countries.

The inequality has an economic as well as a political aspect. The white community is a limited talent pool further depleted as professionals with ability take up opportunities elsewhere. In addition a homogeneous white management team does not reflect South Africa's rich cultural diversity and risks loosing touch with its customer base. Affirmative action is being seen by top managers and politicians as a key issue for many South African companies.

This article examines a framework for identifying and supporting talented black managers based on research published in the context of higher education. In a series of publications we were able to show that the appropriate method of 
identifying gifted but disadvantaged students has quantifiable advantages, among them ease of implementation, self regulation and increased student motivation.

\section{THE DIRECT APPROACH TO AFFIRMATIVE ACTION}

The direct approach to affirmative action places affirmative action candidates directly into positions freed up either passively or through active intervention. Some companies attempting to use direct affirmative action programs are finding the direct approach problematic.

A direct affirmative action program is typically built around a quota concept. Top and middle positions are identified, often with a high level skills inventory. Next a target is agreed and key performance indicators are identified.

One such system measures the opportunities to place affirmative action candidates, the availability of internally trained candidates and the affirmative action climate. These indicators are monitored and individual targets are set. Further targets are developed, monitoring the progress of affirmative action candidates in the organisation. High level indicators are placed on the business dashboard.

Such system must overcome three hurdles. The first hurdle is to provide adequate support for the affirmative action candidate. A manager who is promoted because of skin colour may find himself out of his depth. This is particularly true in a climate of prejudice or resentment.

Secondly there are a limited number of positions with which to experiment. Only once a position is free is it possible to move a manager to a new level of responsibility. With the progressive flattening of organisational structures even these positions are not always being filled.

Finally it proves difficult to provide the systematic safety net needed since not everyone is suitable for a management position. A manager promoted too far above his/her competence may find that he can neither cope nor learn; the new manager might as well retire into the new position.

\section{AFFIRMATIVE ACTION AND THE DUAL SELECTION SYSTEM}

In both higher education and management, we have had success by setting up a simple, flexible parallel structure.

In higher education we asked ourselves how to identify students who are at the same time gifted but disadvantaged (Gering and Zietsman, 1983). Studies had . shown (van Wyk and Crawford, 1984) that the matric rating was the by far the best predictor of university success. This is not surprising since the matric 
examination has the advantage that it measures what university measures, including academic skill, the ability to perform under pressure and the character to remain motivated over an extended period. On the other hand matric rating is strongly biased to current performance.

The solution was to recognise that the school leaving class is a statistically significant control group. A student who performs at top of a poorly performing class is academically gifted but disadvantaged. That he is disadvantaged academically is witnessed by the academic performance of his peer group. That he is gifted academically is witnessed by his performance at the top of his peer group. By labelling the student as disadvantaged, we were able to tailor remedial programs to his or her needs. But by labelling him as gifted, the negative stigma of the disadvantaged could be removed (Zietsman and Gering, 1985).

We tested this hypothesis on a sample of over 1200 students from all racial groups over a three year period. Given two students with identical matric ratings. the student from the disadvantaged background will begin to improve and will show in one year an average improvement of ten percent over the advantaged student. Results were published international journal Higher Education (Gering and Zietsman, 1986a) and the full results presented at a conference in Heidelberg, Germany (Gering and Zietsman, 1986b).

The student therefore has two routes to university admission, the normal route where he competes against the national average and the alternative route where he competes against his peer group. The selection criteria has the advantage of being racially neutral and self regulating. The statistical sample showed that, although clearly black students were more likely than white students to have suffered academic disadvantage, the improvement effect of the gifted but disadvantaged student was not a racial effect per se.

\section{AFFIRMATIVE ACTION IN MANAGEMENT}

While the model for affirmative action in management is not the same as that for education two key principles carry over. The first principle is testing by doing. The second principle is that there are often altemative routes to demonstrate competence, be it managerial or academic.

The management context differs from higher education in that smaller numbers are selected, in a more stringent process and with the intention of long term retention. Moreover the early part of the management career is both a learning and a selection system for later management responsibilities. It is in this context that alternative structures are needed to develop managers who would otherwise not have been given the opportunity to develop. 
Such structures do exist in industry. In the past they were found typically in staff type roles, for example the role of the young finance recruits in conglomerates such as ITT or General Electric. The equivalent structure in the age of delegation and empowerment is that of project team.

An international consulting company has a wide experience of using full time joint team members in large scale change projects. A change project with ten consultants could involve fifteen full time joint team members, up to fifty part time team members and have a duration of eighteen months. The consultants participate in the selection of the joint team and then formally induce, coach and ourplace team members.

The managers face challenging situations. Some rise to the occasion and use the project as a platform for their next career jump. This is true irrespective of management level or of country.

Companies in South Africa increasingly use the project structure as a deliberate opportunity to test black managers in a demanding role. Together with the consultant they select promising candidates. The consultant is then charged with delivering the project but at the same time working closely with the joint team members, coaching them in their unfamiliar role. Some candidates exceed all expectations. These candidates are snapped up by the organisation and move on to a leadership role that they have unreservedly earned and for which they are indisputably ready.

Not all candidates meet the mark. Candidates who do not meet the mark are moved tactfully back into the organisation. This may occur either at the end of the project as a rotation during the project. The candidate has been given a chance without compromising either the aspirations of other candidates or the functioning of the organisation.

\section{THE ADVANTAGES AND PREREQUISITES OF SUCH A STRUCTURE}

Using a project structure as a testing ground for fast track managers offers three advantages. Firstly the system has a safety net. The manager who is struggling has the direct supporn and coaching of a consultant experienced both at solving business problems and at supporting managers in a sink or swim role. The manager who even then cannot cope, goes back into the organisation taking his experience with him, and is not left in a role in which he cannot succeed.

Secondly there is a chance to test many managers. A change project involves up to ten percent of an organisation in part time roles. The opportunity to identify candidates and place them in stretch roles is maximised. Managers in new 
roles, particularly in previously rigid organisations do have the propensity to surprise.

And finally the candidate earns his later top management role. Affirmative action in this model is not aimed at redressing past discrimination. In this model affirmative action is the opportunity of tapping the wider talent pool as a source of competitive advantage.

There are however three important prerequisites, three critical success factors which we have seen threaten such projects. Firstly the role must be a real role in a real project. For example business process reengineering project is ideal. It involves detailed understanding of core business processes and exposes the candidate to interesting interpersonal situations across departments. Business process reengineering projects fail when top management fails to take an active, high profile support role. Top management involvement and a high corporate profile are characteristics of real projects with real roles.

Secondly the project must constitute a leaming situation. Again large scale change constitutes a sink or swim situation involving business skills and people skills equivalent to a protracted business school case study. The project is replacing the postgraduate training that privileged managers in other countries might be afforded.

Finally the program needs tough decisions. A change program which is being used to test potential high fliers needs the involvement of the human resource director and a deliberate planning of later career steps. Many, perhaps most candidates won't make it and the human resource director has a role in facilitating the outplacement and helping the team let go.

\section{CONCLUSION}

Counting in the form of statistical data is almost always a good indicator of past and present discrimination; counting as an action plan in the form of a quota is usually not. A quota system is a method of last resort; it is the tool of very high level management or of external activists; it is the tool of people determined to use blunt force to overcome resistance. Alternative approaches are being used, even in organisations undergoing systematic delayering. 


\section{REFERENCES}

1. GERING, M.Z.I. and ZIETSMAN, A.I. (1983). University Entrance in an Academically Non-Homogeneous Society, South African Journal of Education, 3,181-184.

2. ZIETSMAN, A.I. and GERING, M.Z.I. (1985). Academic Aptitude and Background As Factors in University Admission Policies. South African Journal of Education, 5, 184-187.

3. GERING, M.Z.I. and ZIETSMAN, A.I. (1986a). Admission to University in an Academically Non-Homogeneous Society. Higher Education, 15, 25-35.

4. GERING, M. Z. I. and ZIETSMAN, A. I. (1986b). Quality and Access: a dual criterion admission system for higher education institutions, Twelfth International conference on Improving University Teaching (Heidelberg 1986), 500-509.

5. VAN WYK, J.A. and CRAWFORD, J.L. (1984). Correlation between matric symbols and marks obtained in a first-year ancillary physics course at the University of the Witwatersrand. South African Journal of Science, 80, 8-9. 